\title{
MACRO AND TRACE ELEMENTS IN BARLEY (HORDEUM VULGARE L.) BREEDS IN LATVIA DEPENDING ON VARIETY, ENVIRONMENT, AND AGRICULTURAL PRACTICE
}

\author{
Ida Jākobsone ${ }^{1, \#}$, Sanita Zute ${ }^{2}$, Māra Bleidere ${ }^{2}$, Ināra Kantāne ${ }^{3}$, and Vadims Bartkevičs ${ }^{4}$ \\ ${ }^{1}$ Faculty of Chemistry, University of Latvia, 1 Jelgavas Str., Rīga, LV-1004, LATVIA \\ ${ }^{2}$ Stende Research Centre, Institute of Agricultural Resources and Economics, Dižstende, LV-3258, LATVIA \\ ${ }^{3}$ Faculty of Business, Management and Economics, University of Latvia, 5 Aspazijas Blvd., Rīga, LV-1050, LATVIA \\ ${ }^{4}$ Institute of Food Safety, Animal Health and Environment BIOR, 3 Lejupes Str., Rīga, LV-1076, LATVIA \\ \# Corresponding author, ida.jakobsone@lu.Iv
}

Communicated by Māris K!̣aviṇš

The aim of the study was to determine concentrations of 13 macro and trace elements in different barley genotypes depending on the year of growth $(2011,2012$, and 2013) and agricultural practice (conventional/organic). $\mathrm{Cd}, \mathrm{Pb}, \mathrm{Cr}, \mathrm{Ni}$, and $\mathrm{Al}$ concentrations were determined by electrothermal atomic absorption spectrometry and $\mathrm{K}, \mathrm{Na}, \mathrm{Zn}, \mathrm{Cu}, \mathrm{Ca}, \mathrm{Mg}, \mathrm{Mn}$, and Fe concentrations by flame atomic absorption spectrometry. Statistically different concentrations of $\mathrm{Cr}, \mathrm{Cu}$, and $\mathrm{Zn}$ occurred among genotypes; for $\mathrm{Ca}, \mathrm{Mn}$, and Fe concentrations between barley grains, grown conventionally and organically; for $\mathrm{Cr}$ and Ni concentrations between hulled and hull-less grain and for $\mathrm{Cd}, \mathrm{Cr}, \mathrm{Ni}, \mathrm{Cu}, \mathrm{Zn}, \mathrm{Al}, \mathrm{K}$, and Na concentrations among the study years. Concentrations of potentially hazardous elements were low (Cd<0.005-0.027, $\mathrm{Pb}$ 0.013-0.066, $\mathrm{Cr} 0.111-0.327, \mathrm{Ni}$ 0.161-1.264, Cu 2.8-4.7 and Al 1.62-6.09 $\left.\mathrm{mg} \cdot \mathrm{kg}^{-1}\right)$. Barley products can provide necessary macro and trace elements, especially of $\mathrm{Mn}, \mathrm{Mg}$, Fe, and Zn (7.8-16.1; 1024-1249; 29.2-52.9,

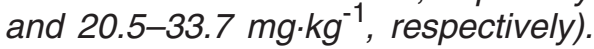

Key words: conventional farming, organic agriculture, statistical indicators, risk assessment, nutritional aspects.

\section{INTRODUCTION}

Cereals are the most important food source for human consumption. From the approximately 2.3 billion tonnes of cereals currently produced, roughly 1 billion tonnes are used as a source of human food and world cereal supplies remain high (Anonymous, 2013). Cereal products provide significant amounts of most nutrients including relevant quantities of minerals and are an important part of a balanced diet in many countries. In Europe the average annual consumption of cereal grains is $131 \mathrm{~kg}$ per capita (Poutanen, 2012).

Barley (Hordeum vulgare L.) is one of the most important cereals grown worldwide and in 2016 barley production in the EU was 59990 thousand tonnes, including 289 thousand tonnes produced in Latvia (Anonymous, 2016), where most of the yield is used for feed. Barley historically has been an important food source in many parts of the world, including in the Middle East, North Africa, Asia and northern and eastern Europe and there is increased interest in barley food because of its nutritional value (Baik and Ulrich,
2008), but human consumption of barley is still relatively low. According to the EU Cereals Balance Sheet for the marketing year 2016/2017, the human use of wheat is 47.8 million tonnes (from total use 117.0 million $\mathrm{t}$ ) and human use of barley is only 0.4 million $t$ (from the total use of cereals 51.0 million t) (Anonymous, 2017).

From the nutritional point of view, attention is mainly focused on essential macro elements $(\mathrm{K}, \mathrm{Ca}$, and $\mathrm{Mg}$ ) and trace elements ( $\mathrm{Fe}, \mathrm{Cu}, \mathrm{Mn}$, and $\mathrm{Zn}$ ) in grain products. Minerals in cereal grain, also in barley, are mostly found in the aleurone layer (Lui et al., 2007; Poultanen, 2012). Mineral and vitamin deficiencies affect a greater proportion of the world's population than does protein energy malnutrition. Even though micronutrients are needed in a minute quantities (i.e. micrograms to milligrams per day), they have a tremendous impact on human health and wellbeing. Insufficient dietary intakes of these nutrients impair the functions of brain, immune and reproductive systems and energy metabolism (Graham et al., 2001). 
Transfer of various elements to the food chain of humans is significantly affected by the geological origin of the soils and the groundwater basin as well as the growing area of the cereals. Some trace elements like $\mathrm{Fe}, \mathrm{Mg}, \mathrm{Zn}$, and $\mathrm{Co}$, are essential micronutrients with a variety of biochemical functions in all living organisms. However, the benefits of these micronutrients may be completely reversed at too high concentrations. Some heavy metals, particularly $\mathrm{Cd}$ and $\mathrm{Pb}$, have been considered as serious soil and environment pollutants due to their toxicity at low concentrations (Korkmaz et al., 2010).

Concentration of toxic heavy metals $(\mathrm{Pb}, \mathrm{Cd}, \mathrm{Cr})$ and their effect on human health and the amounts of essential heavy metals $(\mathrm{Ni}, \mathrm{Cu}, \mathrm{Zn})$ in agricultural products have been reported previously (Pirsaheb et al., 2015). $\mathrm{Pb}$ and $\mathrm{Cd}$ are very toxic even at low concentrations, $\mathrm{Cr}$ is carcinogen, but it is essential at low concentrations, $\mathrm{Ni}$ can be toxic, but normally occurs at very low concentrations, and $\mathrm{Zn}$ and $\mathrm{Cu}$ are needed for humans at certain levels.

Hull-less barley as a whole grain cereal with increased content of soluble fibre has been recognised as more valuable and economic in the food industry than covered barley, because of interest of consumers and publicity on healthy food products (Baik and Ullrich, 2008). Research on hull-less barley and its cultivation is now receiving more emphasis and indicates potential for various end uses, also in Latvia (Bleidere et al., 2013a; 2013b). Unlike hulled barley, it is possible to use hull-less barley in food products directly without de-hulling. The outer parts of grain, which contain more dietary quality related compounds, including macro and trace elements, can be included in food.

The quality of human life depends on the chemical composition of food and on the environment (Kabata-Pendias, 2011). Soil is the main source of trace elements for plants, both of micronutrients and pollutants (Kabata-Pendias and Mukherjee, 2007). The macro and trace element contents of plants are affected by the cultivar of plant, soil conditions, weather conditions during the period of growth, use of fertilisers and the state of the plant maturity at harvest (Kabata-Pendias, 2011). As agriculture is the primary source of all micronutrients for human consumption, agricultural systems must contribute to dysfunctional food systems failing to meet the nutritional needs of everyone (Welch and Graham, 2005).

Demand for organic agriculture and environmentallyfriendly agricultural products is increasing worldwide. In this respect, it is not known whether and how different agriculture techniques and/or cultivation systems may affect the composition of nutrients in the final product. Comparison of organic and conventional foods in terms of nutritional value, sensorial quality and food safety has often highlighted controversial results. As a consequence, a clear link between cultivation system and nutritional profile of agricultural products is still missing (Bourn and Prescott, 2002).
The aim of the study was to determine macro and trace element concentrations in different barley genotypes depending on environment and agricultural practice, and evaluate risks regarding $\mathrm{Cd}, \mathrm{Pb}, \mathrm{Cr}, \mathrm{Ni}, \mathrm{Cu}$, and $\mathrm{Zn}$ concentrations in barley and nutritional aspects regarding $\mathrm{K}, \mathrm{Na}, \mathrm{Ca}, \mathrm{Mn}, \mathrm{Mg}$, $\mathrm{Fe}, \mathrm{Cu}, \mathrm{Zn}$, and $\mathrm{Cr}$ concentrations in barley.

\section{MATERIALS AND METHODS}

Soil, climate and agronomical practice. Grain cultivation was carried out from 2011 to 2013 at the Stende Research Centre (SRC) $\left(57^{\circ} 11 ' 35^{\prime} " \mathrm{~N}, 22^{\circ} 33\right.$ '19" E, $>80 \mathrm{~m}$ above mean see level). Barley was cultivated both organically and conventionally as described further.

Organic field. The soil type was sod-podzolic, sandy loam and loamy sand (Eutric Abeluvisols sandy loam). Organic substance concentration was $20.2-21.6 \mathrm{mg} \cdot \mathrm{kg}^{-1}, \mathrm{pH}_{\mathrm{KCl}}$ was 5.27-5.89, and concentration of plant-available phosphorus $\left(\mathrm{P}_{2} \mathrm{O}_{5}\right)$ was $138-164 \mathrm{mg} \cdot \mathrm{kg}^{-1}$, and of potassium $\left(\mathrm{K}_{2} \mathrm{O}\right)-$ $130-175 \mathrm{mg} \cdot \mathrm{kg}^{-1}$. Common agronomic practices for organic management were used during the vegetation period.

Conventional field. The soil type in the conventional field was sod-podzolic, sandy loam and loamy sand (Eutric Abeluvisols sandy loam), concentration of organic substances was 21-24 mg. $\mathrm{kg}^{-1}, \mathrm{pH}_{\mathrm{KCl}}$ was 5.4-5.8, available phosphorus $\left(\mathrm{P}_{2} \mathrm{O}_{5}\right)$ concentration was $137.0-158.8 \mathrm{mg} \cdot \mathrm{kg}^{-1}$, and of potassium $\left(\mathrm{K}_{2} \mathrm{O}\right)-175.7-211.0 \mathrm{mg} \cdot \mathrm{kg}^{-1}$. The experimental treatment consisted of three $\mathrm{N}$ rates - N80, N120, and N160 in conventional growing conditions. Complex mineral fertiliser was used as a basic fertiliser at the rate $725 \mathrm{~kg} \cdot \mathrm{ha}^{-1}$ $\left(\mathrm{N}-80, \mathrm{P}-28.6, \mathrm{~K}-112.4 \mathrm{~kg} \cdot \mathrm{ha}^{-1}\right)$. The application of $\mathrm{N}$ was split, part was applied at the time of sowing and the remaining half at the end of the tillering stage (growing stage/GS 29) of the crop. Ammonium nitrate (N 34\%) was used as top-fertiliser in the following amounts: $40 \mathrm{~kg} \mathrm{~N}$ per ha (N120) and $80 \mathrm{~kg} \mathrm{~N}$ per ha (N160). The treatments were laid out in a randomised complete block design; the plot size was $10 \mathrm{~m}^{2}$ and four replicates were used.

Weather conditions. The average air temperature from April to August differed annually in the period 2011-2013 (Table $1)$. The most significant differences in temperature were noticed in June: $13{ }^{\circ} \mathrm{C}$ in 2012) and $17{ }^{\circ} \mathrm{C}$ in 2011 and 2013). Temperature was similar in August in all study years (15.5 to $\left.16.6{ }^{\circ} \mathrm{C}\right)$. Precipitation differences between the study years (Table 1) were most significant in July - 36 (2013) to $165 \mathrm{~mm}$ (2011). The weather conditions were warmer than long-term average observations with heavy rainfall occasionally during the growing period of 2011.

Description of the studied barley. In cooperation with the Stende Research Centre the following barley cultivars/genotypes were used in the study: three hull-less genotypes '1185', 'Kornelija', '1165', and hulled variety 'Ansis'. Hull-less breeding line ' 1185 ' is characterised by high grain yield, starch, $\alpha$-tocopherol concentration and radical scavenging activity, line ' 1165 ' has high total phenol concentra- 
AVERAGE TEMPERATURE AND PRECIPITATION SUM AT STENDE, 2011-2013

\begin{tabular}{l|cccc|c|c|c|c|c}
\hline \multirow{2}{*}{ Month } & \multicolumn{3}{|c|}{ Average temperature, ${ }^{\circ} \mathrm{C}$} & \multicolumn{4}{c}{ Precipitation sum, mm } \\
\cline { 2 - 9 } & 2011 & 2012 & 2013 & Norm & 2011 & 2012 & 2013 & Norm \\
\hline April & 6.9 & 5.6 & 4.0 & 4.3 & 26.8 & 42.7 & 34.9 & 37 \\
May & 10.6 & 11.0 & 13.7 & 10.2 & 54.7 & 58.9 & 86.1 & 45 \\
June & 16.8 & 13.2 & 16.9 & 14.2 & 59.6 & 78.7 & 74.5 & 57 \\
July & 19.2 & 17.5 & 16.9 & 16.3 & 165.3 & 91.7 & 36.2 & 87 \\
August & 16.3 & 15.5 & 16.6 & 15.5 & 155.0 & 115.1 & 45.2 & 87 \\
Average & 14.0 & 12.6 & 13.6 & 12.1 & 92.3 & 77.4 & 55.3 & 62.6
\end{tabular}

tion, and variety 'Kornelija' has high crude protein and $\beta$-glucan concentration in grain (Bleidere et al., 2013a; Bleidere et al., 2013b). Hulled barley 'Ansis' is a widely grown variety in Latvia. In the article coding is used for designation of the growing system (Table 2).

Barley genotypes were sown with a compact trial drill "Hege 80" in a well prepared seedbed at a rate of 500 germinating seeds per $\mathrm{m}^{2}$. The plot size was $10 \mathrm{~m}^{2}$ and four replicates were used. The yield was harvested using a combine "Hege 140". Sampling was done according to the ISO 950 Cereals-Sampling (as Grain) standard.

Analysis of macro and trace elements. Concentrations of thirteen macro and trace elements $(\mathrm{Cd}, \mathrm{Pb}, \mathrm{Ni}, \mathrm{Cr}, \mathrm{Al}, \mathrm{Cu}$, $\mathrm{K}, \mathrm{Na}, \mathrm{Mn}, \mathrm{Fe}, \mathrm{Zn}, \mathrm{Mg}, \mathrm{Ca}$ ) were determined in cereal grain samples $(n=48)$ provided by the Stende Research Centre (collected in 2011-2013). Average moisture content in the grain was $10-13 \%$.

Sample mineralisation. Grain was ground and 0.5-1.0 g was weighed in a crucible, which was placed in a muffle furnace with a programmable heating regime. Grain samples were dried for $1 \mathrm{~h}$ at $110{ }^{\circ} \mathrm{C}$; then the temperature was increased $\left(50{ }^{\circ} \mathrm{C} \mathrm{h}^{-1}\right)$ until $450{ }^{\circ} \mathrm{C}$ and held for eight hours. Then the crucible was removed from the muffle furnace and cooled to room temperature, and 1-3 $\mathrm{ml}$ of water was added to the dry residue. This procedure was repeated until light grey or white ash was obtained. Then $2 \mathrm{ml} 6 \mathrm{M} \mathrm{HCl}$ were added and evaporated. The residue was dissolved in $25 \mathrm{ml} 0.1 \mathrm{M}$ $\mathrm{HNO}_{3}$ (Anonymous, 1999). The obtained solutions were used for chemical analysis.
Concentrations of five elements $(\mathrm{Cd}, \mathrm{Cr}, \mathrm{Al}, \mathrm{Pb}$, and $\mathrm{Ni}$ ) were determined by electrothermal atomic absorption spectrometry with Zeeman background correction (ETAAS; Perkin Elmer AAnalyst 600, Shelton, USA) after dry digestion, and concentrations of eight elements $(\mathrm{K}, \mathrm{Na}, \mathrm{Zn}, \mathrm{Cu}$, $\mathrm{Ca}, \mathrm{Mg}, \mathrm{Mn}$, and $\mathrm{Fe}$ ) were determined by flame atomic absorption spectrometry (FAAS; Perkin Elmer AAnalyst 800, Shelton, USA).

Quality assurance. Analytical performance of the applied procedure was checked by the intra-laboratory validation procedure in accordance to the Commission Regulation (EC) No. 333.2007. Relative standard deviation \% and accuracy within the interval $70-115 \%$ was obtained for all elements. Quantification limits of the applied analytical procedure varied between $0.005 \mathrm{mg} \cdot \mathrm{kg}^{-1}$ (cadmium) and 1 $\mathrm{mg} \cdot \mathrm{kg}^{-1}$ (potassium and sodium). In addition, the analytical procedure was successfully checked (z-score below 2) by participation in the proficiency testing rounds organised by the European Union Reference Laboratory.

Data processing. For statistical analysis, the data were processed using the IBM Corp. Released 2013. IBM SPSS Statistics for Windows, Version 22.0. Armonk, NY: IBM Corp.

For data analysis descriptive statistics and non-parametric statistics methods (Kruskal-Wallis test and Mann-Whitney test) were used.

Human exposure and nutritional value assessment. Calculation of use of grain and grain products in Latvia was done using the data of the Central Statistical Bureau of Latvia on consumption of flour, dough, flakes, bread, pasta, pizza, pastry etc. per capita in 2015 (Anonymous, 2015a). The calculated human consumption was $\sim 130 \mathrm{~g}$ per day per capita.

The values of Estimated Weekly Intake (EWI) or Estimated Daily Intake (EDI) were calculated using a formula published previously (Anonymous, 2005) and modified by Reinholds et al. (2017):

$D=C \times 0.13 \times \frac{T}{60}$

where: D (= EWI or EDI) — exposure dose in $\mu \mathrm{g} \cdot \mathrm{kg}^{-1}$ per week (or per day) per $\mathrm{kg}$ of body weight, $\mathrm{C}$ - element concentration $\mu \mathrm{g} \cdot \mathrm{kg}^{-1}$ grain, 0.13 — human intake of grain

Table 2

DESCRIPTION AND CODING SYSTEM OF THE BARLEY SAMPLES

\begin{tabular}{|c|c|c|c|c|}
\hline \multicolumn{2}{|r|}{ Coding system } & \multirow[t]{2}{*}{ Lines } & \multirow[t]{2}{*}{ Description } & \multirow[t]{2}{*}{ Additional information } \\
\hline Genotype + & growing systems & & & \\
\hline 1185 & (1) Grown organically: & Simba/Wanubet & hull-less barley breeding line & SRC breeding material \\
\hline 1165 & (2-4) Grown conventionally: & Gainer/Freedom & hull-less barley breeding line & SRC breeding material \\
\hline Ansis & +80 N supply 80 kg/ha etc. & - & hulled, widely grown malting barley variety & breed at SRC, 1999 \\
\hline
\end{tabular}

Example of coding: ‘ 1185 ’ $+\mathrm{BIO}$ - genotype 1185 grown organically; ‘ 1185 ’ +80 - genotype 1185 grown conventionally with $\mathrm{N}$ supply $80 \mathrm{~kg} \cdot$ ha ${ }^{-1}$; SRC, Stende Research Centre 
products in $\mathrm{kg}$ per capita per day, and $\mathrm{T}=7$ days per week (or $\mathrm{T}=1$ for daily intake), 60 - theoretical weight of human body $60 \mathrm{~kg}$. The results were compared with published data and recommendations.

\section{RESULTS}

Concentrations of macro elements in four barley genotypes depending on growing conditions (conventional growing with three different nitrogen supplies and organic growing) are shown in Table 3.

Potassium (K) concentration was from $3914 \mathrm{mg} \cdot \mathrm{kg}^{-1}$ in 'Kornelija' +160 to $4801 \mathrm{mg} \cdot \mathrm{kg}^{-1}$ in , 1185 ” +80 , sodium (Na) concentration from $49 \mathrm{mg} \cdot \mathrm{kg}^{-1}$ in 'Ansis'+BIO to 142 $\mathrm{mg} \cdot \mathrm{kg}^{-1}$ in 'Kornelija' +80 , calcium (Ca) concentration was from $276 \mathrm{mg} \cdot \mathrm{kg}^{-1}$ in ' $1165^{\prime}+\mathrm{BIO}$ to $447 \mathrm{mg} \cdot \mathrm{kg}^{-1}$ in 'Ansis'+80 (see Table 3). K, Na, and Ca concentrations did not significantly differ between barley genotypes (KruskalWallis test, $p>0.05$ ).

Magnesium (Mg) concentration was from $1024 \mathrm{mg} \cdot \mathrm{kg}^{-1}$ in ' 1185 ' +160 to $1249 \mathrm{mg} \cdot \mathrm{kg}^{-1}$ in 'Kornelija'+120 (see Table 3). $\mathrm{Mg}$ concentration between barley genotypes significantly differed (Kruskal-Wallis test $\chi^{2}=12.626, p=$ 0.006). $\mathrm{Mg}$ concentration significantly differed between barley varieties 'Kornelija' and '1185' (pairwise comparisons with Bonferroni correction, adjusted $p=0.012$ ).
Iron ( $\mathrm{Fe}$ ) concentration was from $29.2 \mathrm{mg} \cdot \mathrm{kg}^{-1}$ in ' 1185 ' + BIO to $52.9 \mathrm{mg} \cdot \mathrm{kg}^{-1}$ in 'Kornelija' +120 (see Table 3). Fe concentration between barley genotypes significantly differed (Kruskal-Wallis test, $\chi 2=15.002, p=0.002$ ). Fe concentration significantly differed between barley varieties '1185' and 'Kornelija' and also '1185' and 'Ansis' (pairwise comparisons with Bonferroni correction, adjusted $p$-values 0.001 , and 0.047 , respectively).

Concentrations of trace elements in four barley genotypes depending on growing conditions (conventional growing with three different nitrogen supplies and organic growing) are shown in Table 4.

Cadmium $(\mathrm{Cd})$ concentration was under the detection limit in 3 samples (' $1185+120$, ' 1185 ' BIO and ' 1165 ' BIO) and the highest value was $0.027 \mathrm{mg} \cdot \mathrm{kg}^{-1}$, in 'Kornelija' +80 (see Table 4). The concentration of $\mathrm{Cd}$ did not significantly differ between barley genotypes (Kruskal-Wallis test, $p>$ $0.05)$.

Lead $(\mathrm{Pb})$ concentration was from $0.013 \mathrm{mg} \cdot \mathrm{kg}^{-1}$ in ' 1165 ' +80 to $0.066 \mathrm{mg} \cdot \mathrm{kg}^{-1}$ in 'Kornelija' +120 (see Table 4). $\mathrm{Pb}$ concentration did not significantly differ between barley genotypes (Kruskal-Wallis test, $p>0.05$ ).

Chromium $(\mathrm{Cr})$ concentration was from $0.111 \mathrm{mg} \cdot \mathrm{kg}^{-1}$ in ' 1185 ' +80 to $0.327 \mathrm{mg} \cdot \mathrm{kg}^{-1}$ in 'Ansis' +120 (see Table 4). The concentration of $\mathrm{Cr}$ between barley genotypes significantly differed (Kruskal-Wallis test $\chi 2=8.506, p=0.037$ ).

Table 3

CONCENTRATIONS OF MACRO ELEMENTS IN BARLEY GENOTYPES DEPENDING ON GROWING CONDITIONS, $\mathrm{mg} \cdot \mathrm{kg}^{-1}$

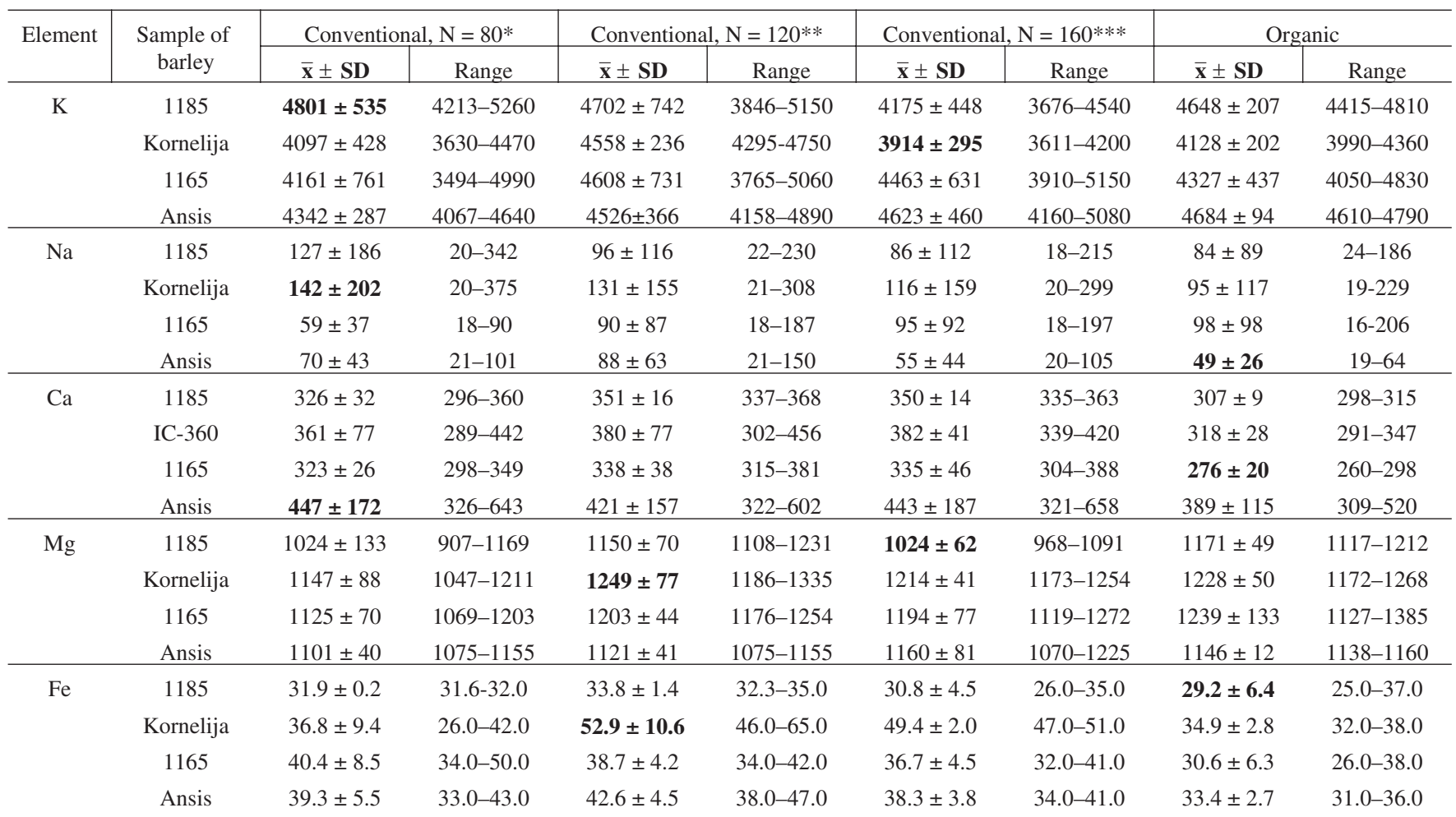

* $\mathrm{N}=80-\mathrm{N}$ supply $80 \mathrm{~kg} \cdot \mathrm{ha}^{-1}, * * \mathrm{~N}=120-\mathrm{N}$ supply $120 \mathrm{~kg} \cdot \mathrm{ha}^{-1}$, *** $\mathrm{N}=160-\mathrm{N}$ supply $160 \mathrm{~kg} \cdot \mathrm{ha}^{-1}$

Average value \pm SD and range presents results from the year 2011, 2012, and 2013; highest and lowest concentrations for each element in bold 
CONCENTRATIONS OF TRACE ELEMENTS IN BARLEY GENOTYPES DEPENDING ON GROWING CONDITIONS, $\mathrm{mg} \mathrm{kg}^{-1}$

\begin{tabular}{|c|c|c|c|c|c|c|c|c|c|}
\hline \multirow[t]{2}{*}{ Element } & \multirow{2}{*}{$\begin{array}{c}\text { Sample of } \\
\text { barley }\end{array}$} & \multicolumn{2}{|c|}{ Conventional, $\mathrm{N}=80^{*}$} & \multicolumn{2}{|c|}{ Conventional, $\mathrm{N}=120 * *$} & \multicolumn{2}{|c|}{ Conventional, $\mathrm{N}=160 * * *$} & \multicolumn{2}{|c|}{ Organic } \\
\hline & & $\overline{\mathbf{x}} \pm \mathbf{S D}$ & Range & $\overline{\mathbf{x}} \pm \mathbf{S D}$ & Range & $\overline{\mathbf{x}} \pm \mathbf{S D}$ & Range & $\overline{\mathbf{x}} \pm \mathbf{S D}$ & Range \\
\hline \multirow[t]{3}{*}{$\mathrm{Cd}$} & 1185 & $0.006 \pm 0.002$ & $<0.005-0.008$ & $<0.005$ & $<0.005$ & $0.007 \pm 0.004$ & $<0.005-0.012$ & $<0.005$ & $<0.005$ \\
\hline & 1165 & $0.006 \pm 0.003$ & $<0.005-0.009$ & $0.009 \pm 0.005$ & $0.005-0.014$ & $0.007 \pm 0.005$ & $<0.005-0.013$ & $<0.005$ & $<0.005$ \\
\hline & Ansis & $0.007 \pm 0.002$ & $<0.005-0.009$ & $0.014 \pm 0.009$ & $0.007-0.024$ & $0.012 \pm 0.012$ & $<0.005-0.026$ & $0.007 \pm 0.005$ & $.005-0.013$ \\
\hline \multirow[t]{4}{*}{$\mathrm{Pb}$} & 1185 & $0.023 \pm 0.013$ & $<0.010-0.035$ & $0.028 \pm 0.018$ & $<0.010-0.046$ & $0.030 \pm 0.027$ & $<0.010-0.060$ & $0.017 \pm 0.006$ & $0.013-0.024$ \\
\hline & Kornelija & $0.028 \pm 0.016$ & $<0.010-0.039$ & $0.066 \pm 0.067$ & $<0.010-0.140$ & $0.024 \pm 0.011$ & $0.013-0.035$ & $0.019 \pm 0.008$ & $0.012-0.028$ \\
\hline & 1165 & $0.013 \pm 0.006$ & $<0.010-0.020$ & $0.015 \pm 0.006$ & $<0.010-0.021$ & $0.020 \pm 0.008$ & $0.013-0.028$ & $0.020 \pm 0.003$ & $0.018-0.023$ \\
\hline & Ansis & $0.018 \pm 0.012$ & $<0.010-0.032$ & $0.025 \pm 0.015$ & $<0.010-0.040$ & $0.035 \pm 0.016$ & $<0.010-0.021$ & $0.014 \pm 0.004$ & $<0.010-0.018$ \\
\hline \multirow[t]{3}{*}{$\mathrm{Cr}$} & 1185 & $0.111 \pm 0.041$ & $0.076-0.157$ & $0.120 \pm 0.009$ & $0.115-0.131$ & $0.155 \pm 0.076$ & $0.072-0.221$ & $0.145 \pm 0.091$ & $0.068-0.245$ \\
\hline & Kornelija & $0.245 \pm 0.170$ & $0.075-0.415$ & $0.219 \pm 0.163$ & $0.086-0.400$ & $0.259 \pm 0.206$ & $0.094-0.490$ & $0.182 \pm 0.118$ & $0.110-0.318$ \\
\hline & 1165 & $0.200 \pm 0.172$ & $0.085-0.398$ & $0.131 \pm 0.048$ & $0.095-0.185$ & $0.197 \pm 0.110$ & $0.087-0.306$ & $0.125 \pm 0.094$ & $0.058-0.233$ \\
\hline \multirow[t]{4}{*}{$\mathrm{Ni}$} & 1185 & $0.240 \pm 0.310$ & $0.055-0.598$ & $0.161 \pm 0.148$ & $0.055-0.330$ & $0.187 \pm 0.223$ & $<0.05-0.444$ & $0.277 \pm 0.391$ & $<0.05-0.729$ \\
\hline & Kornelija & $0.242 \pm 0.300$ & $0.064-0.588$ & $0.326 \pm 0.460$ & $<0.05-0.857$ & $0.187 \pm 0.220$ & $<0.05-0.440$ & $0.222 \pm 0.278$ & $<0.05-0.542$ \\
\hline & 1165 & $0.314 \pm 0.442$ & $0.056-0.824$ & $0.178 \pm 0.204$ & $<0.05-0.413$ & $1.264 \pm 2.073$ & $<0.05-3.657$ & $0.223 \pm 0.293$ & $<0.05-0.561$ \\
\hline & Ansis & $1.102 \pm 1.625$ & $0.104-2.977$ & $0.440 \pm 0.471$ & $0.080-0.973$ & $0.305 \pm 0.236$ & $0.063-0.535$ & $0.387 \pm 0.286$ & $0.058-0.574$ \\
\hline \multirow[t]{4}{*}{$\mathrm{Cu}$} & 1185 & $2.8 \pm 1.3$ & 1.7-4.2 & $3.4 \pm 1.1$ & $2.3-4.5$ & $3.2 \pm 1.2$ & $1.9-4.2$ & $4.1 \pm 1.0$ & $3.2-5.2$ \\
\hline & Kornelija & $4.1 \pm 1.6$ & $2.7-5.9$ & $4.7 \pm 1.1$ & $3.5-5.7$ & $4.0 \pm 0.3$ & $3.8-4.4$ & $4.1 \pm 0.3$ & $3.8-4.4$ \\
\hline & 1165 & $3.5 \pm 0.5$ & $2.9-3.9$ & $3.1 \pm 0.7$ & $2.4-3.7$ & $3.5 \pm 0.2$ & $3.3-3.7$ & $3.8 \pm 0.3$ & $3.4-4.0$ \\
\hline & Ansis & $3.5 \pm 0.5$ & $3.1-4.0$ & $3.6 \pm 0.5$ & $3.2-4.1$ & $3.0 \pm 0.2$ & $2.8-3.2$ & $3.3 \pm 0.6$ & $2.7-3.8$ \\
\hline \multirow[t]{4}{*}{$\mathrm{Zn}$} & 1185 & $22.2 \pm 7.6$ & $18.0-31.0$ & $22.9 \pm 8.8$ & $17.0-33.0$ & $20.5 \pm 7.4$ & $16.0-29.0$ & $22.0 \pm 2.7$ & $19.0-24.0$ \\
\hline & Kornelija & $30.5 \pm 13.5$ & $22.0-46.0$ & $33.7 \pm 16.0$ & $22.0-52.0$ & $32.3 \pm 11.00$ & $26.0-45.0$ & $26.7 \pm 3.5$ & $23.0-30.0$ \\
\hline & 1165 & $23.2 \pm 7.7$ & $18.0-32.0$ & $24.1 \pm 6.9$ & $19.0-32.0$ & $23.6 \pm 8.4$ & $17.0-33.0$ & $22.0 \pm 2.7$ & $19.0-24.0$ \\
\hline & Ansis & $20.8 \pm 3.7$ & $18.0-25.0$ & $24.3 \pm 8.4$ & $19.0-34.0$ & $23.0 \pm 8.7$ & $18.0-33.0$ & $26.3 \pm 6.8$ & $21.0-34.0$ \\
\hline \multirow{2}{*}{$\mathrm{Al}$} & 1165 & $2.37 \pm 0.90$ & $1.33-2.95$ & $3.01 \pm 1.24$ & $1.67-4.13$ & $1.62 \pm 0.50$ & $1.14-2.14$ & $2.31 \pm 0.53$ & $1.73-2.78$ \\
\hline & Ansis & $3.10 \pm 1.74$ & $1.20-4.61$ & $2.83 \pm 1.67$ & $1.14-4.48$ & $2.81 \pm 2.06$ & $0.89-4.98$ & $2.95 \pm 1.17$ & $1.61-3.78$ \\
\hline \multirow[t]{4}{*}{ Mn } & 1185 & $10.4 \pm 1.5$ & $9.1-12.0$ & $12.6 \pm 1.5$ & $11.0-14.0$ & $11.5 \pm 1.3$ & $10.0-12.5$ & $8.7 \pm 1.0$ & $7.7-9.8$ \\
\hline & Kornelija & $13.8 \pm 1.6$ & $12.0-15.0$ & $16.1 \pm 1.1$ & $15.0-17.2$ & $15.9 \pm 1.8$ & $14.0-17.6$ & $11.7 \pm 4.7$ & $8.8-17.1$ \\
\hline & 1165 & $11.9 \pm 0.12$ & $11.8-12.0$ & $12.5 \pm 0.9$ & $12.0-13.6$ & $13.2 \pm 1.4$ & $12.0-14.7$ & $7.8 \pm 1.6$ & $6.7-9.7$ \\
\hline & Ansis & $11.3 \pm 1.2$ & $10.0-12.0$ & $13.9 \pm 1.0$ & $13.0-15.0$ & $14.1 \pm 1.0$ & $13.0-15.0$ & $9.3 \pm 1.0$ & $8.2-10.0$ \\
\hline
\end{tabular}

* $\mathrm{N}=80-\mathrm{N}$ supply $80 \mathrm{~kg} \cdot \mathrm{ha}^{-1}, * * \mathrm{~N}=120-\mathrm{N}$ supply $120 \mathrm{~kg} \cdot \mathrm{ha}^{-1}, * * * \mathrm{~N}=160-\mathrm{N}$ supply $160 \mathrm{~kg} \cdot \mathrm{ha}^{-1}$

Average value \pm SD and range represents results from the years 2011,2012, and 2013; highest and lowest concentrations for particular element in bold

Cr concentration significantly differed between barley varieties 'Ansis' and '1185', and also 'Ansis' and '1165' (Mann-Whitney test, $\mathrm{z}=-2.656, p=0.008 ; \mathrm{z}=-2.136, p=$ 0.033 , respectively).

Nickel (Ni) concentration was from $0.161 \mathrm{mg} \cdot \mathrm{kg}^{-1}$ in ' 1185 ' +120 to $1.264 \mathrm{mg} \cdot \mathrm{kg}^{-1}$ in ' $11655^{\prime}+160$ (see Table 4). Concentration of $\mathrm{Ni}$ did not significantly differ between barley genotypes (Kruskal--Wallis test, $p>0.05$ ).

Copper $(\mathrm{Cu})$ concentration was from $2.8 \mathrm{mg} \cdot \mathrm{kg}^{-1}$ in ' 1185 ' +80 to $4.74 \mathrm{mg} \cdot \mathrm{kg}^{-1}$ in 'Kornelija'+120 (see Table 4).

The differences of $\mathrm{Cu}$ concentration between barley genotypes were statistically significant (Kruskal-Wallis test $\chi 2=9.000, p=0.029)$. $\mathrm{Cu}$ concentration significantly dif- fered between barley varieties 'Kornelija' and 'Ansis', and also 'Kornelija' and '1165' (Mann-Whitney test, $\mathrm{z}=$ $-2.744, p=0.006 ; \mathrm{z}=-2.430, p=0.015$, respectively).

Zinc $(\mathrm{Zn})$ concentration was from $20.5 \mathrm{mg} \cdot \mathrm{kg}^{-1}$ in ' 1185 ' +160 to $33.7 \mathrm{mg} \cdot \mathrm{kg}^{-1}$ in 'Kornelija'+120 (see Table 4). $\mathrm{Zn}$ concentration significantly differed between barley genotypes (Kruskal-Wallis test $\chi 2=8.441, p=0.038$ ). Zn concentration significantly differed between barley genotypes ' 1185 ' and 'Kornelija', between '1165' and 'Kornelija', and also between 'Kornelija' and 'Ansis' (Mann-Whitney test, $\mathrm{z}=-2.250, p=0.024 ; \mathrm{z}=-2.195, p=$ $0.028 ; \mathrm{z}=-2.139, p=0.032$, respectively).

Aluminium $(\mathrm{Al})$ concentration was from $1.62 \mathrm{mg} \cdot \mathrm{kg}^{-1}$ in ' 1165 ' +160 to $6.09 \mathrm{mg} \cdot \mathrm{kg}^{-1}$ in 'Kornelija'+BIO (see Table 
4). Al concentration did not significantly differ between barley genotypes (Kruskal-Wallis test, $p>0.05$ ).

Manganese $(\mathrm{Mn})$ concentration was from $7.8 \mathrm{mg} \cdot \mathrm{kg}^{-1}$ in ' 1165 '+BIO to $16.1 \mathrm{mg} \cdot \mathrm{kg}^{-1}$ in 'Kornelija'+120 (see Table 4). Mn concentration significantly differed between barley genotypes (Kruskal--Wallis test, $\chi 2=11.306, p=0.010$ ). Mn concentration significantly differed between barley varieties 'Kornelija' and '1185' (pairwise comparisons with Bonferroni correction, adjusted $p$-value $=0.010$ ). Eriksson (2001) reported concentration of $\mathrm{Mn}$ in barley to range from $12-34 \mathrm{mg} \cdot \mathrm{kg}^{-1}$ (average $18 \mathrm{mg} \cdot \mathrm{kg}^{-1}$ ).

Concentration of macro and trace elements in barley depending on conventional or organic practices. The average concentrations of $\mathrm{Cd}, \mathrm{Pb}, \mathrm{Cr}, \mathrm{Ni}, \mathrm{Cu}$, and $\mathrm{Zn}$ did not significantly differ (Mann-Whitney test, $p>0.220$ ) between organically or conventionally (with different $\mathrm{N}$ supply) grown barley genotypes (Table 5).

The highest $\mathrm{Cd}, \mathrm{Pb}, \mathrm{Cr}, \mathrm{Ni}$, and $\mathrm{Zn}$ concentrations were in barley genotypes grown conventionally. The variability of $\mathrm{Cd}, \mathrm{Pb}, \mathrm{Cr}$, and $\mathrm{Ni}$ concentration in barley genotypes grown conventionally was also high. The highest $\mathrm{Cu}$ concentration with low variability was in barley genotypes grown organically.

The highest $\mathrm{K}$ and $\mathrm{Mg}$ concentrations with lowest variability were in barley genotypes grown organically. The highest Mn concentration with lower variability occurred in barley genotypes grown conventionally. The variability of $\mathrm{Al}$ and $\mathrm{Na}$ concentration was high in barley genotypes grown conventionally and grown organically. The variability of $\mathrm{K}, \mathrm{Ca}$, $\mathrm{Mn}, \mathrm{Mg}$, and Fe concentration was low in barley genotypes grown conventionally and grown organically. In general, the variability of $\mathrm{Al}, \mathrm{K}, \mathrm{Na}, \mathrm{Ca}, \mathrm{Mn}, \mathrm{Mg}$, and $\mathrm{Fe}$ concentration was lower in barley genotypes grown organically than in genotypes grown conventionally.

Table 5

CONCENTRATIONS OF MACRO AND TRACE ELEMENTS IN BARLEY DEPENDING ON CONVENTIONAL OR ORGANIC GROWING CONDITIONS, $\mathrm{mg} \cdot \mathrm{kg}^{-1}$

\begin{tabular}{c|c|c}
\hline & $\begin{array}{c}\text { Conventional (with different N } \\
\text { supply) }(\mathrm{n}=36)\end{array}$ & Organic $(\mathrm{n}=12)$ \\
\hline $\mathrm{Cd}$ & $0.011 \pm 0.012$ & $0.006 \pm 0.002$ \\
$\mathrm{~Pb}$ & $0.025 \pm 0.024$ & $0.017 \pm 0.006$ \\
$\mathrm{Cr}$ & $0.214 \pm 0.140$ & $0.178 \pm 0.128$ \\
$\mathrm{Ni}$ & $0.412 \pm 0.765$ & $0.277 \pm 0.278$ \\
$\mathrm{Cu}$ & $3.53 \pm 0.90$ & $3.82 \pm 0.63$ \\
$\mathrm{Zn}$ & $25.1 \pm 9.1$ & $24.3 \pm 4.3$ \\
$\mathrm{Al}$ & $3.02 \pm 1.84$ & $3.52 \pm 3.05$ \\
$\mathrm{~K}$ & $4414 \pm 509$ & $4447 \pm 331$ \\
$\mathrm{Na}$ & $96 \pm 104$ & $81 \pm 79$ \\
$\mathrm{Ca}$ & $371 \pm 89$ & $323 \pm 67$ \\
$\mathrm{Mn}$ & $13.1 \pm 2.0$ & $9.4 \pm 2.7$ \\
$\mathrm{Mg}$ & $1143 \pm 91$ & $1196 \pm 76$ \\
$\mathrm{Fe}$ & $39.3 \pm 8.0$ & $32.0 \pm 4.8$
\end{tabular}

Average value \pm SD represents results from the years 2011, 2012, and 2013
The concentrations of $\mathrm{Ca}, \mathrm{Mn}$, and Fe significantly differed between organically or conventionally (with different $\mathrm{N}$ supply) grown barley genotypes (Mann-Whitney test $p<$ 0.005). The concentrations of $\mathrm{Al}, \mathrm{K}, \mathrm{Na}$, and $\mathrm{Mg}$ did not significantly differ between organically or conventionally grown barley genotypes (Mann-Whitney test, $p>0.140$ ).

Concentration of macro and trace elements in hulled and hull-less barley. The highest $\mathrm{Cd}, \mathrm{Cr}$, and $\mathrm{Ni}$ concentrations were in hulled grains ('Ansis'); $\mathrm{Pb}, \mathrm{Cu}$, and $\mathrm{Zn}$ concentrations were higher in hull-less grains (Table 6). In hulled barley grains the variability of $\mathrm{Cd}, \mathrm{Pb}, \mathrm{Cr}, \mathrm{Ni}, \mathrm{Cu}$, and $\mathrm{Zn}$ was lower than in hull-less grains. The variability of $\mathrm{Cd}, \mathrm{Cr}$, and $\mathrm{Ni}$ concentration in barley genotypes was high. The variability of $\mathrm{Pb}$ concentrations was high in hull-less barley grains but low in hulled grains. The variability of $\mathrm{Cu}$ and $\mathrm{Zn}$ concentration in barley genotypes was moderate.

The concentrations of $\mathrm{Cd}, \mathrm{Pb}, \mathrm{Cu}$, and $\mathrm{Zn}$ did not significantly differ between hulled and hull-less grains (MannWhitney test, $p$ 0.113). The concentrations of $\mathrm{Cr}$ and $\mathrm{Ni}$ significantly differed between hulled and hull-less grains (Mann-Whitney test, $p=0.012 ; p=0.045$, respectively).

In hulled barley grains the variability of $\mathrm{Al}, \mathrm{K}, \mathrm{Na}, \mathrm{Mn}, \mathrm{Mg}$, and $\mathrm{Fe}$ was lower than in hull-less grain although the variability of $\mathrm{Al}$ and $\mathrm{Na}$ concentrations in hulled grains and in hull-less grains was high. The variability of $\mathrm{Ca}$ was higher in hull-less barley grains. The highest $\mathrm{K}, \mathrm{Mn}$, and Fe concentrations with lower variability were in hulled grains than in hull-less grains. The concentrations of $\mathrm{Al}, \mathrm{K}, \mathrm{Na}, \mathrm{Ca}$, $\mathrm{Mn}, \mathrm{Mg}$, and Fe did not significantly differ between hulled and hull-less grain (Mann-Whitney test, $p>0.116$ ).

Concentration of macro and trace elements in barley depending on year. The concentration range of some elements is rather wide (Table 7). Weather conditions (air tem-

Table 6

CONCENTRATIONS OF MACRO AND TRACE ELEMENTS IN HULLED AND HULL-LESS BARLEY, $\mathrm{mg} \cdot \mathrm{kg}^{-1}$

\begin{tabular}{c|c|c}
\hline & $\begin{array}{c}\text { Hull-less barley }(1185, \\
\text { Kornelija, 1165) }(\mathrm{n}=36)\end{array}$ & $\begin{array}{c}\text { Hulled barley (Ansis) } \\
(\mathrm{n}=12)\end{array}$ \\
\hline $\mathrm{Cd}$ & $0.009 \pm 0.011$ & $0.011 \pm 0.008$ \\
$\mathrm{~Pb}$ & $0.025 \pm 0.023$ & $0.018 \pm 0.001$ \\
$\mathrm{Cr}$ & $0.174 \pm 0.113$ & $0.297 \pm 0.164$ \\
$\mathrm{Ni}$ & $0,318 \pm 0.627$ & $0.559 \pm 0.810$ \\
$\mathrm{Cu}$ & $3.69 \pm 0.93$ & $3.33 \pm 0.45$ \\
$\mathrm{Zn}$ & $25.3 \pm 8.6$ & $23.6 \pm 6.5$ \\
$\mathrm{Al}$ & $3.22 \pm 2.39$ & $2.92 \pm 1.45$ \\
$\mathrm{~K}$ & $4382 \pm 507$ & $4544 \pm 313$ \\
$\mathrm{Na}$ & $102 \pm 109$ & $65 \pm 43$ \\
$\mathrm{Ca}$ & $337 \pm 45$ & $425 \pm 138$ \\
$\mathrm{Mn}$ & $12.2 \pm 2.9$ & $12.2 \pm 2.3$ \\
$\mathrm{Mg}$ & $1164 \pm 99$ & $1132 \pm 49$ \\
$\mathrm{Fe}$ & $37.2 \pm 8.7$ & $38.4 \pm 5.0$
\end{tabular}

Average value \pm SD represents results from the years 2011, 2012, and 2013 
CONCENTRATIONS OF MACRO AND TRACE ELEMENTS IN BARLEY IN 2011, 2012, AND 2013 DEPENDING ON ORGANIC OR CONVENTIONAL GROWING CONDITIONS, $\mathrm{mg} \cdot \mathrm{kg}^{-1}$

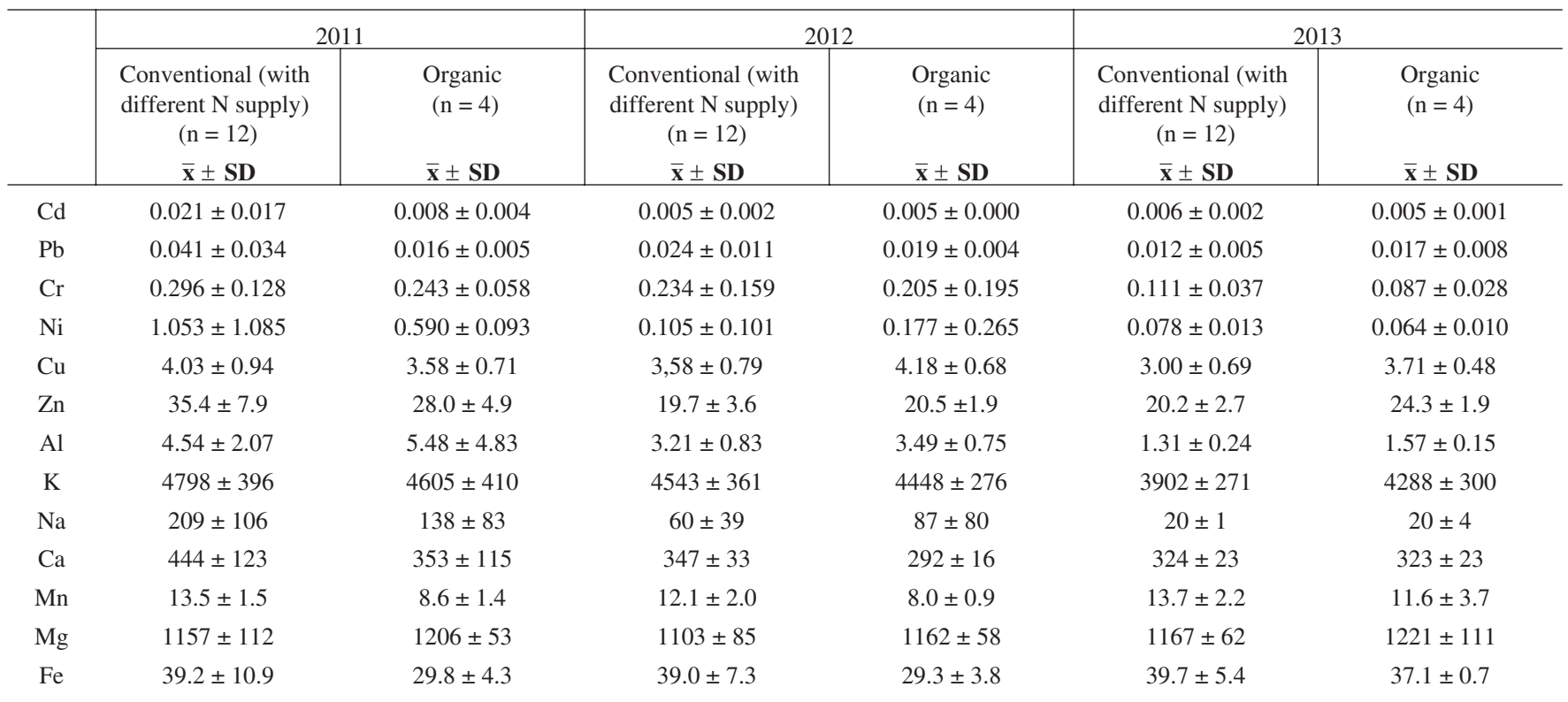

perature and rainfall, see Table 1) evidently had an effect. It has previously been reported that bioavailability of trace elements depends on conditions of the environment (moisture, temperature) (Pinto et al., 2014).

In 2011, the grain from organic farming contained less $\mathrm{Cd}$, $\mathrm{Pb}, \mathrm{Cr}, \mathrm{Ni}$, and $\mathrm{Zn}$ than grain from conventional farming, but the reverse occurred in other years (excepting for $\mathrm{Cr}$ ).

$\mathrm{Cd}, \mathrm{Pb}, \mathrm{Cr}, \mathrm{Ni}, \mathrm{Ca}, \mathrm{Zn}, \mathrm{Al}, \mathrm{K}$, and $\mathrm{Na}$ concentrations in barley grains significantly differed (Kruskal-Wallis test, $p$ 0.011 ) between years (see Table 7). Cd, Ni, Zn, Na, and Ca concentrations in grain significantly differed between 2011 and 2012 and also between 2011 and 2013 (pairwise comparisons with Bonferroni correction, adjusted $p$-value < 0.011). $\mathrm{Pb}, \mathrm{Cr}, \mathrm{Al}$, and $\mathrm{K}$ concentrations in grain significantly differed between 2011 and 2013 and also between 2012 and 2013 (pairwise comparisons with Bonferroni correction, adjusted $p$-value $<0.022$ ).

\section{DISCUSSION}

The mean and median data for all 48 barley samples, compared with values from Finland, Austria, Bulgaria, Pakistan, and north of Saudi Arabia, as well as data from soil analyses in Latvia and in Pakistan, are shown in Table 8. Element concentrations in samples from European countries (Finland, Austria, and Bulgaria) are in the same range as in our study. In many cases soil of Pakistan contains higher concentrations of macro and trace elements than in Latvia (with the exception of $\mathrm{Pb}$ ), and correspondingly the grain from Pakistan contains higher levels of macro and trace elements (with the exception of $\mathrm{Cu}, \mathrm{Zn}, \mathrm{K}, \mathrm{Na}, \mathrm{Ca}, \mathrm{Mn}$, and $\mathrm{Mg}$ ). In grain samples from Saudi Arabia only $\mathrm{Cd}$ and $\mathrm{Pb}$ had higher concentrations then in samples from Latvia and other European countries (Table 8).
Other studies, not reflected in Table 8, showed different ranges of $\mathrm{Cd}$ concentration in barley samples: $\mathrm{Cd}$ concentration $0.013-0.022 \mathrm{mg} \cdot \mathrm{kg}^{-1}$ in barley (Kabata-Pendias, 2011); Cd concentration 0.014 to $0.084 \mathrm{mg} \cdot \mathrm{kg}^{-1}$ (mean $0.039 \mathrm{mg} \cdot \mathrm{kg}^{-1}$, concentration of $\mathrm{Cd}$ in the soil was $0.0-0.295 \mathrm{mg} \cdot \mathrm{kg}^{-1}$ ) in barley grown adjacent to roadways in Poland (Wieczorek et al., 2005)

According to European Commission Regulation 488/2014 (Anonymous, 2014a) the maximum allowed concentration of $\mathrm{Cd}$ in grain is $0.10 \mathrm{mg} \cdot \mathrm{kg}^{-1}$. This value was exceeded in barley samples from Pakistan and Saudi Arabia (see Table 8).

A linear relationship between $\mathrm{Cd}$ concentrations in plant material and growth media has been reported. In many publications, soil $\mathrm{pH}$ is listed as the major soil factor controlling both total and relative uptake of $\mathrm{Cd}$. Soil type also affects uptake of $\mathrm{Cd}$ by plants. For soils with the same total $\mathrm{Cd}$ concentration, $\mathrm{Cd}$ has been found to be more soluble and more plant-available in sandy soil than in clay soil (He and Singh, 1994).

Eriksson (2001) reported a concentration range of $0.007-0.028 \mathrm{mg} \cdot \mathrm{kg}^{-1} \mathrm{~Pb}$ (mean $0.013 \mathrm{mg} \cdot \mathrm{kg}^{-1}$ ) in barley. $\mathrm{Pb}$ concentration in grains grown adjacent to roadways in Poland was from 0.16 to $0.76 \mathrm{mg} \cdot \mathrm{kg}^{-1}$ (mean $0.27 \mathrm{mg} \cdot \mathrm{kg}^{-1}$, concentration of $\mathrm{Pb}$ in the soil was $3-68 \mathrm{mg} \cdot \mathrm{kg}^{-1}$ ) (Wieczorek et al. 2005).

According to European Commission Regulation 2015/1005 (Anonymous, 2015b) the maximum allowed concentration of $\mathrm{Pb}$ in grain is $0.20 \mathrm{mg} \cdot \mathrm{kg}^{-1}$; this value was exceeded in most samples from Poland (near roadways), and in Pakistan and Saudi Arabia (see Table 8). 
Table 8 COMPARISON OF MACRO AND TRACE ELEMENT CONCENTRATIONS IN BARLEY GRAIN AND IN SOIL OF DIFFERENT REGIONS, $\mathrm{mg}^{-\mathrm{kg}^{-1}}$

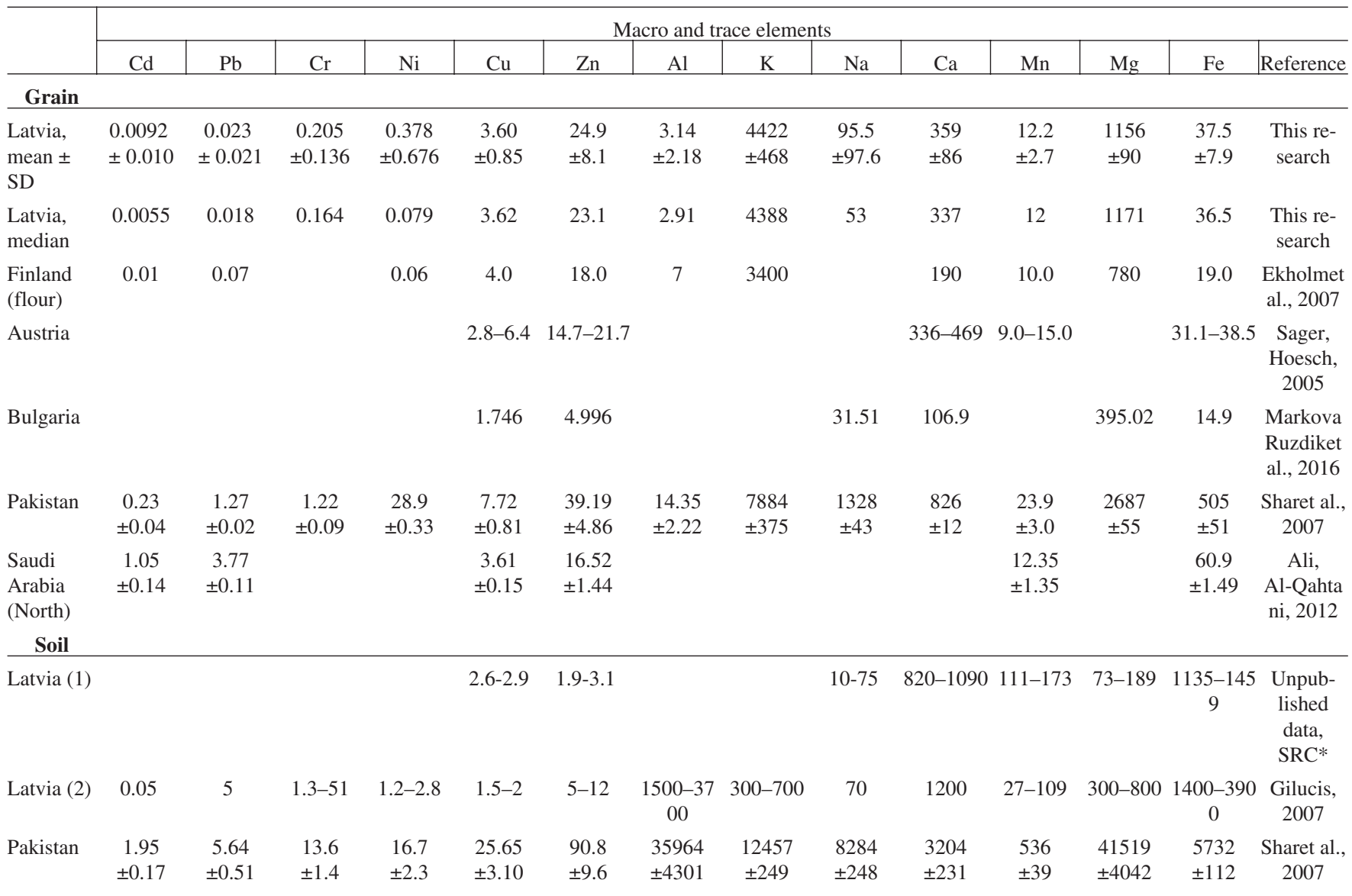

* SRC, Stende Research Centre

The great variation of $\mathrm{Pb}$ content in plants is caused by several environmental factors, like geochemical anomalies, pollution, seasonal variation, and genotype accumulation ability. Genotype factors cause distinctive differences in the concentrations (Alexander et al., 2006).

Kabata-Pendias (2011) summarised information on the concentration range $\left(4-15 \mathrm{mg} \cdot \mathrm{kg}^{-1}\right)$ and mean $\left(5.5 \mathrm{mg} \cdot \mathrm{kg}^{-1}\right)$ of $\mathrm{Cu}$ in barley. Phytobioavailability and toxicity of $\mathrm{Cu}$ differs between chemical species. Several soil variables control $\mathrm{Cu}$ solubility and thus its bioavailability; these factors include $\mathrm{pH}$, oxidation and reduction potential, soil texture, mineral composition, temperature, and water regime (KabataPendias and Sadurski, 2004).

The immobilisation of $\mathrm{Zn}$ in soils is highly controlled by phosphorous and clays (Kumpiene et al., 2008). Zn toxicity and tolerance in plants have recently been of special concern because of the prolonged use of $\mathrm{Zn}$ fertilisers, as well as its input from industrial pollution causing raised $\mathrm{Zn}$ concentration of surface soils. Several plant species and genotypes are known to have high tolerance to $\mathrm{Zn}$ and a great selectivity in absorbing Zn from soils (Kabata-Pendias, 2011).

Ciołek et al. (2012) reported K concentration of 4912 $\mathrm{mg} \cdot \mathrm{kg}^{-1}$ in barley and Ca concentration of $306 \mathrm{mg} \cdot \mathrm{kg}^{-1}$ in barley. Cereals frequently do not respond to $\mathrm{K}$ fertilisation and wheat is more sensitive to $\mathrm{K}$ deficiency than barley (Askegaard et al., 2004). Cultivars of the same species may differ in ability to exploit soil $\mathrm{K}$ resources.

Kan (2015) reported $\mathrm{Na}$ concentration in barley to be 124 $\mathrm{mg} \cdot \mathrm{kg}^{-1}$ (in the range of our data), and observed slightly little higher Ca concentration $-487 \mathrm{mg} \cdot \mathrm{kg}^{-1}$.

$\mathrm{Mn}$ is one of the most abundant trace elements in the lithosphere. Several soil factors influence Mn availability to plants. The solubility of soil Mn is of significance since the plant supply of Mn depends mainly on the soluble Mn pool in the soil. In well-drained soils, the solubility of Mn always increases with increase of soil acidity. However, the ability of $\mathrm{Mn}$ to form anionic complexes and to complex with organic ligands may contribute to increased Mn solubility in the alkaline $\mathrm{pH}$ range. $\mathrm{Mn}$ mobility and its availability to plants increase at pH 5.5 (Kabata-Pendias, 2011).

Other studies (Ciołek et al., 2012) have found lower Mg concentration $\left(802 \mathrm{mg} \cdot \mathrm{kg}^{-1}\right)$ or higher $\mathrm{Mg}$ concentration (1667 $\left.\mathrm{mg} \cdot \mathrm{kg}^{-1}\right)($ Kan 2015).

Kabata-Pendias (2011) summarised data on Fe concentration in various grains and roots. Fe concentrations in barley 
grains were in the range $33-218 \mathrm{mg} \cdot \mathrm{kg}^{-1}$ (mean 98 $\mathrm{mg} \cdot \mathrm{kg}^{-1}$ ).

Risk assessment regarding $\mathrm{Cd}, \mathrm{Cr}, \mathrm{Pb}, \mathrm{Ni}, \mathrm{Cu}$, and $\mathrm{Zn}$ concentration in barley. To evaluate the health risk due to $\mathrm{Cd}, \mathrm{Cr}, \mathrm{Pb}, \mathrm{Ni}, \mathrm{Cu}$, and $\mathrm{Zn}$ concentration in barley, the mean concentration was calculated for all 48 samples (Table 9). The Estimated Weekly Intake (EWI) was calculated presuming that the weekly consumption of grain $(130 \mathrm{~g}$ day $^{-1}$ per 7 days) consisted only of barley. Such approach seems acceptable, as previously (Jakobsone et al., 2015) it was shown that concentrations of heavy elements are low in all grain species grown in Latvia and used for human consumption.

The calculated values of EWI were compared with the Potential Tolerable Weekly Intake (PTWI) reported previously (Pirsaheb et al., 2015).

Consumption of $130 \mathrm{~g}$ barley grain products per day did not reach the limit of PTWI for $\mathrm{Cd}, \mathrm{Pb}, \mathrm{Cr}, \mathrm{Ni}$, and $\mathrm{Cu}$. In the case of $\mathrm{Zn}$, the calculated $90 \%$ of EWI/PTWI should be significantly lower, if bioavailability of $\mathrm{Zn}$ is taken in account (Table 9). According to WHO/FAO (Anonymous, 2004) in the case of cereal grains the assumed bioavailability for $\mathrm{Zn}$ from cereal grains is only $15-30 \%$.
Nutritional aspects associated with $\mathrm{Al}, \mathrm{K}, \mathrm{Na}, \mathrm{Ca}, \mathrm{Mn}$, $\mathrm{Mg}, \mathrm{Fe}, \mathrm{Cu}, \mathrm{Zn}$, and $\mathrm{Cr}$ concentration in barley. To evaluate nutritional aspects associated with $\mathrm{Al}, \mathrm{K}, \mathrm{Na}, \mathrm{Ca}$, $\mathrm{Mn}, \mathrm{Mg}, \mathrm{Fe}, \mathrm{Cu}, \mathrm{Zn}$, and $\mathrm{Cr}$ concentrations in barley, the mean concentration was calculated for all 48 samples (Table 10). Daily consumption was calculated presuming that all grain products $(130 \mathrm{~g})$ consist only of barley.

Calculated consumption data were compared with recommendations for daily intake given by the Latvian Ministry of Health (Anonymous, 2013; 2014b), tolerable daily intakes or upper limit of safe range of WHO (Anonymous, 1996) and tolerable daily intakes reported by EFSA (Anonymous, 2006). The highest contribution of barley grain in the recommended intake was for $\mathrm{Mn}, \mathrm{Mg}, \mathrm{Fe}$, and $\mathrm{Zn}$ (53, $43,27-49$, and $23 \%$ of values given in recommendations of Latvian Ministry of Health, respectively).

\section{ACKNOWLEDGMENTS}

The authors acknowledge financial support from the European Social Fund project No. 2013/0072/1DP/1.1.1.2.0/13/ APIA/VIAA/032.

Table 9

MEAN CONCENTRATIONS, ESTIMATED WEEKLY INTAKE (EWI) AND POTENTIAL TOLERABLE WEEKLY INTAKE (PTWI) OF Cd, Pb, Cr, $\mathrm{Ni}$, , and $\mathrm{Zn}$

\begin{tabular}{l|c|c|c|c|cc}
\hline \multicolumn{1}{c|}{ Element } & $\mathrm{Cd}$ & $\mathrm{Pb}$ & $\mathrm{Cr}$ & $\mathrm{Ni}$ & $\mathrm{Cu}$ & $\mathrm{Zn}$ \\
\hline Mean concentration, $\mathrm{mg} \cdot \mathrm{kg}^{-1}$ & 0.0093 & 0.0234 & 0.205 & 0.378 & 3.60 & 24.9 \\
EWI, $\mu \mathrm{g} \cdot \mathrm{kg}^{-1}$ of body weight & 0.14 & 0.35 & 3.1 & 5.7 & 54 & 378 \\
PTWI, $\mu \mathrm{g} \cdot \mathrm{kg}^{-1}$ of body weight* & 7 & 25 & 23.3 & 35 & 500 & 420 \\
EWI/PTWI100\% & 2 & 1.4 & 13.3 & 16.3 & 10.8 & 90
\end{tabular}

* Pirsaheb et al. (2015)

POSSIBLE CONTRIBUTION OF GRAIN IN THE RECOMMENDED (OR TOLERABLE) DAILY INTAKE OF SOME ELEMENTS

\begin{tabular}{|c|c|c|c|c|c|c|c|c|c|c|}
\hline Element & $\mathrm{Al}$ & $\mathrm{K}$ & $\mathrm{Na}$ & $\mathrm{Ca}$ & $\mathrm{Mn}$ & $\mathrm{Mg}$ & $\mathrm{Fe}$ & $\mathrm{Cu}$ & $\mathrm{Zn}$ & $\mathrm{Cr}$ \\
\hline Mean concentration, $\mathrm{mg} \cdot \mathrm{kg}^{-1}$ & 3.1 & 4422 & 92.5 & 359 & 12.2 & 1156 & 37.5 & 3.6 & 24.9 & 0.205 \\
\hline \multicolumn{11}{|c|}{ Recommended (or tolerable) intake (mg) by: } \\
\hline Latvian Ministry of Health $(\mathrm{MoH})$ & & $4000^{1}$ & $3300^{1}$ & $1000-1200^{1}$ & $3^{2}$ & $350^{1}$ & $10-18^{2}$ & $3^{2}$ & $14^{2}$ & $0.2^{2}$ \\
\hline $\mathrm{TDI}^{3}$ or $\mathrm{USF}^{4}$ of WHO, 1996 & $1^{3}$ & & & & & & & $10-12^{4}$ & $35-45^{4}$ & $0.25^{4}$ \\
\hline TDI $^{3}$ of EFSA, 2006 & & 3000 & 1500 & $900-1200$ & & 250 & 25 & 5 & 25 & 1 \\
\hline \multicolumn{11}{|l|}{ Daily consumption, present work, in: } \\
\hline $\mathrm{mg}$ & 0.40 & 575 & 12 & 47 & 1.6 & 150 & 4.9 & 0.47 & 3.2 & 0.027 \\
\hline$\%$ from recommendations of $\mathrm{MoH}$ & & 14.4 & 0.4 & $3.9-4.7$ & 53 & 43 & $27-49$ & 16 & 23 & 13.5 \\
\hline$\%$ from limits of WHO & 40 & & & & & & & $3.9-4.7$ & $7-9$ & 11 \\
\hline$\%$ from TDI of EFSA & & 19 & 0.4 & 1.9 & & 60 & 19.6 & 9.4 & 13 & 2.7 \\
\hline \multicolumn{11}{|c|}{${ }^{1} \mathrm{MoH}, 2014$, recommended daily intake } \\
\hline \multicolumn{11}{|c|}{${ }^{2} \mathrm{MoH}, 2013$, recommended daily intake } \\
\hline${ }^{3}$ USF, upper limit of safe range & & & & & & & & & & \\
\hline${ }^{4}$ TDI, tolerable daily intake & & & & & & & & & & \\
\hline
\end{tabular}




\section{REFERENCES}

Alexander, P. D., Alloway, B. J., Dourado, A. M. (2006). Genotypic variation in the accumulation of $\mathrm{Cd}, \mathrm{Cu}, \mathrm{Pb}$ and $\mathrm{Zn}$ exhibited by six commonly grown vegetables. Environment Pollution, 144, 736-745.

Ali, Mohamed, H. H., Al-Qahtani, K. M. (2012). Assessment of some heavy metals in vegetables, cereals and fruits in Saudi Arabian markets. Egypt. J. Aquatic Res., 38, 31-37.

Anonymous (1996). Trace Elements in Human Nutrition and Health. WHO, $343 \mathrm{pp}$.

Anonymous (1999). AOAC official method 999.11. Determination of lead, cadmium, copper, iron and zinc in foods. Atomic absorption spectrophotometry after dry ashing. First action 1999.

Anonymous (2004). Vitamin and Mineral Requirements in Human Nutrition. 2nd ed. WHO and FAO. 341 pp. Available at:

http://apps.who.int/iris/bitstream/10665/42716/1/9241546123.pdf (accessed at 03.03.2017).

Anonymous (2005). Public Health Assessment Guidance Manual. Appendix G: Calculating Exposure Doses. Agency of Toxic Substances and Disease Registry. Available at:

https://www.atsdr.cdc.gov/hac/phamanual/appg.html (accessed at 09.01.2017).

Anonymous (2013). FAO Statistical Year Book. World Food and Agriculture, Food and Agriculture Organisation of the United Nations, Rome. 289 pp. Available at: (http://www.fao.org/docrep/018/i3107e/i3107e.PDF) (accessed 03.03.2017).

Anonymous (2006). Tolerable Upper Intake Levels for Vitamins and Minerals. European Food Safety Authority, Brussels. 480 pp.

Anonymous (2013). Ministry of Health of the Republic of Latvia, Healthy Food, Microelements, 2013 (in Latvian). Available at

http://www.vm.gov.lv/lv/tava_veseliba/veseligs_uzturs/mikroelementi/ (accessed 17.02.2017).

Anonymous (2014a). Commission Regulation (EU) No 488/2014 amending Regulation (EC) No. 1881/2006 as regards maximum levels of cadmium in foodstuffs. Available at: http://data.europa.eu/eli/reg/2014/488/oj (accessed 4 April 2018).

Anonymous (2014b). Ministry of Health of the Republic of Latvia. Healthy Food, Mineral Substances (in Latvian). Available at

http://www.vm.gov.lv/lv/tava_veseliba/veseligs_uzturs/mineralvielas/ (accessed 17.02.2017)

Anonymous (2015a). Central Statistical Bureau (CSB) of the Republic of Latvia, MBG161. Consumption of food products average per household member per year (ECOICOP), 2015. Available at:

http://data.csb.gov.lv/pxweb/en/Sociala/Sociala_ikgad_mb/MB0161.p $\mathrm{x} /$ ?rxid=e 2bfcd $92-\mathrm{a} 7 \mathrm{dc}-43 \mathrm{cf}-961 \mathrm{~d}-\mathrm{e} 4 \mathrm{c} 8 \mathrm{~b} 9 \mathrm{ff} 5 \mathrm{eef}$ (accessed at 25.01.2017).

Anonymous (2015b). Commission Regulation (EU) 2015/1005 amending Regulation (EC) No. 1881/2006 as regards maximum levels of lead in certain foodstuffs. Available at: http://data.europa.eu/eli/reg/2015/1005/oj (accessed 4 April 2018).

Anonymous (2016). Barley by area, production and humidity. Eurostat. Available at:

http://ec.europa.eu/eurostat/tgm/refreshTableAction.do?tab=table $\&$ plugin $=1 \&$ pcode $=\operatorname{tag} 00051 \&$ language $=e n($ accessed at 03.03.2017).

Anonymous (2017). EU Cereals Balance sheet 2016/2017 and forecast 2017/2018; Committee for the Common Organisation of Agricultural Markets, 28th February, 2017. Available at: https://ec.europa.eu/agriculture/sites/agriculture/files/cereals/presentations/-oilseeds/balance-sheets-and-forecasts_en.pdf (accessed at 11.03.2017).

Askegaard, M., Eriksen, J., Johnston, A. E. (2004). Sustainable management of potassium. In: Managing Soil Quality: Challenges in Modern Agriculture. Schjønning, P., Elmholt, S., Christensen, B. T. (eds.). CABI Publishing, pp. 85-102.
Baik, B.-K., Ullrich, S. E. (2008). Barley for food: Characteristics, improvement, and renewed interest. J. Cereal Sci., 48, 233-242.

Bleidere, M., Zute, S., Brunava, L., Bobere, N., Jakobsone, I. (2013a). Yield and grain quality of hulless spring barley in field trials under different nitrogen management conditions. Proc. Latvian Acad. Sci., Section B, 67 (3), 229-235.

Bleidere, M., Zute, S., Jakobsone, I. (2013b). Characterisation of physical and biochemical traits of hulless spring barley grain in Latvian breeding program. Proc. Latvian Acad. Sci., Section B, 67 (4/5), 399-404.

Bourn, D., Prescott, J. (2002). A comparison of the nutritional value, sensory qualities, and food safety of organically and conventionally produced foods. Crit. Rev. Food Sci. Nutr., 42, 1-34.

Ciołek, A., Makarska, E., Wesołowski, M., Cierpiała, R. (2012).Content of selected nutrients in wheat, barley and oat grains from organic and conventional farming. J. Elementol., 2, 181-189.

Ekholm, P., Reinivuo, H., Mattila, P., Pakkala, H., Koponen, J., Happonen, A., Hellström, J., Ovaskainen, M.-L. (2007). Changes in the mineral and trace element contents of cereals, fruit and vegetables in Finland. J. Food Compos. Anal., 20, 487-495.

Eriksson, J. E. (2001). Concentrations of 61 trace elements in sewage sludge, farmyard manure, mineral fertilizers, precipitation and in oil and crops. Swedish EPA. Rep 5159. Stockholm. 69 pp. Available at: http://swedishepa.se/Documents/publikationer/620-6246-8.pdf (accessed 4 April 2018)

Gilucis, A. (2007). Relevancies of Content and Distribution of Trace and Major Elements in the Latvian Topsoils. Doctoral Thesis. University of Latvia, Riga, 88 pp. (in Latvian). Available at:

http://www3.acadlib.lv/greydoc/Gilucis_disertacija/Gilucis.pdf (accessed at 17.02.2017)

Graham, R., Welch, R., Bouis, H. (2001). Addressing micronutrient malnutrition through the nutritional quality of staple foods: Principles, perspectives, and knowledge gaps. Adv. Agron., 70, 77-142.

He, Q. B., Singh, B. R. (1994). Effect of organic matter on the distribution, extractability and uptake of cadmium in soils. Eur. J. Soil Sci., 44 (4), 641-650.

Jākobsone, I., Kantāne, I., Zute, S., Jansone, I., Bartkevičs, V. (2015). Macro-elements and trace elements in cereal grains cultivated in Latvia. Proc. Latvian Acad. Sci., Section B, 69 (4), 152-157.

Kabata-Pendias, A., Sadurski, W. (2004). Trace elements and compounds in soil. In: Elements and Their Compounds in the Environment. $2^{\text {nd }}$ ed. Merian, E., Anke, M., Ihnat, M., Stoeppler, M. Wiley-VCH, Weinheim, pp. 79-99.

Kabata-Pendias, A. (2011). Trace Elements in Soils and Plants. Taylor and Francis Group, LLC, CRC Press. 534 pp.

Kabata-Pendias, A., Mukherjee, A.B. (2007). Trace Elements from Soil to Human. Springer-Verlag, Berlin. 550 pp.

Kan, A. (2015). Characterization of the fatty acid and mineral composition of selected cereal cultivars from Turkey. Rec. Nat. Prod. J., 9 (1), 124-134.

Korkmaz, K., Kara, S. M., Ozkutlu, F., Gul, V. (2010). Monitoring of heavy metals and selected micronutrients in hempseeds from north-western Turkey. Afr. J. Agricult. Res., 5, 463-467.

Kumpiene, J., Lagerkvist, A., Naurice, C. (2008). Stabilization of As, Cr, Cu, $\mathrm{Pb}$, and $\mathrm{Zn}$ in soil using amendments: Review. Waste Management, 28, 215-225.

Lui, K., Peterson, K. L., Raboy, V. (2007). Comparison of the phosphorus and mineral concentrations in bran and abraded kernel fractions of a normal barley (Hordeum vulgare) cultivar versus four low phytic acid isolines. $J$. Agricult. Food Chem., 55 (11), 4453-4460.

Markova Ruzdik, N., Mihajlov, Lj., Llieva, V., Ivanovska, S., Valcheva, D., Balabanova, B., Lievski, M. (2016). Determination of some macro and mi- 
cro elements in grain of winter barley genotypes. Agricult. Science Technol., 8 (1), 51-57.

Pinto, E., Aguiar, A. A. R. M., Ferreira, I. M. P. L. V. O. (2014). Influence of soil chemistry and plant physiology in the phytoremediation of $\mathrm{Cu}, \mathrm{Mn}$ and Zn. Crit. Rev. Plant Sci., 33, 351-373.

Pirsaheb, M., Fattahi, N., Sharafi, K., Khamotian, R., Atafar, Z. (2015). Essential toxic heavy metals in cereals and agricultural products marketed in Kermanshan, Iran, and human health risk assessment. Food Add. Contamin., B, 9 (1). Available at:

http://dx.doi.org/10.1080/19393210.2015.1099570 (accessed at 17.02.2017)

Poutanen, K. (2012). Past and future of cereal grains as food for health. Trends Food Sci. Technol., 25, 58-62.

Reinholds, I., Pugajeva, I., Bavrins, K., Kuckovska, G, Bartkevics, V. (2017). Mycotoxins, pesticides and toxic metals in commercial spices and herbs. Food Add. Contamin, B, 10 (1) Available at: http://dx.doi.org/10.1080/19393210.2016.1210244 (accessed at 15.03.2017)

Sager, M., Hoesch, J. (2005). Macro- and micro element levels in cereals grown in lower Austria. J. Centr. Eur. Agricult., 6 (4), 461-472.

Schjønning, P., Elmholt, S., Christensen, B. T. (2003). Managing Soil Quality: Challenges in Modern Agriculture. CABI Publishing. 368 pp.

Shar, G. Q., Shar, L. A., Kazi, T. G., Afridi, H. I., Arain, M. B., Jamali, M. K. (2007). Multielement analysis of Pakistani barley (Hordeum vulgare L.) varieties by flame atomic absorption spectrometry. Journal of Research (Science), Bahauddin Zakariya University (Pakistan), 18 (2), 69-77.

Welch, R. M., Graham, R. D. (2005). Agriculture: The real nexus for enhancing bioavailable micronutrients in food crops. J. Trace Elem. Med. Biol., 18, 299--307.

Wieczorek, J., Wieczorek, Z., Bieniaszewski, T. (2005). Cadmium and lead content in cereal grains and soil from cropland adjacent to roadways. Polish J. Environ. Studies, 14 (4), 535-540.

Received 27 March 2018

Accepted in the final form 10 April 2018

\section{MAKRO- UN MIKROELEMENTI LATVIJĀ AUDZĒTOS MIEŽOS (HORDEUM VULGARE L.) ATKARĪBĀ NO ŠK̦IRNES, VIDES UN LAUKSAIMNIECĪBAS PRAKSES}

Pētījuma mērkis bija noteikt 13 makro- un mikroelementu koncentrāciju dažādos miežu škirṇu genotipos atkarībā no audzēšanas gada (2011, 2012, 2013) un lauksaimniecības prakses (konvencionālā un bioloğiskā). Cd, Pb, Cr, Ni un Al noteica ar elektrotermisko atomu absorbcijas spektrometru, K, Na, Zn, Cu, Ca, Mg, Mn, Fe noteica ar liesmas atomu absorbcijas spektrometru. Statistiski atškirīgas elementu koncentrācijas tika konstatētas $\mathrm{Cr}, \mathrm{Cu}$ un $\mathrm{Zn}$ gadījumā starp dažādiem genotipiem; Ca, Mn un Fe starp konvencionāli un bioloğiski audzētiem miežu graudiem; $\mathrm{Cr}$ un Ni starp plēkšņgraudu un kailgraudu miežu graudiem un $\mathrm{Cd}, \mathrm{Cr}, \mathrm{Ni}, \mathrm{Cu}, \mathrm{Zn}, \mathrm{Al}, \mathrm{K}$ un $\mathrm{Na}$ starp pētījumu gadiem. Potenciāli bīstamo elementu koncentrācijas bija zemas (Cd 0,005-0,027; Pb 0,013-0,066; Cr 0,111-0,327; Ni 0,161-1,264; Cu 2,8-4,7 un Al 1,62-6,09 mg. $\left.\mathrm{kg}^{-1}\right)$. Miežu produkti var dot ieguldījumu nepieciešamo makro- un mikroelementu patēriņā, îpaši Mn, Mg, Fe un Zn nodrošinājumam (attiecīgi 7,8-16,1; 1024-1249; 29,2-52,9 un 20,5-33,7 $\mathrm{mg} \cdot \mathrm{kg}^{-1}$ ). 